\title{
Predictive value of postoperative C-reactive protein-to-albumin ratio in anastomotic leakage after esophagectomy
}

\author{
Chi Zhang ${ }^{1}$, Xiao Kun Li $i^{*}$, Li Wen Hu' ${ }^{1}$ Chao Zheng ${ }^{2}$, Zhuang Zhuang Cong ${ }^{1}$, Yang $\mathrm{Xu}^{3}$, Jing Luo ${ }^{1}$, \\ Gao Ming Wang ${ }^{4}$, Wen Feng Gu' ${ }^{1}$, Kai Xie ${ }^{3}$, Chao Luo ${ }^{5}$ and Yi Shen ${ }^{1,2,3,4,5^{*}}$ (D)
}

\begin{abstract}
Introduction: Among the many possible postoperative complications, anastomotic leakage (AL) is the most common and serious. Therefore, the purpose of this study was to explore the ability of various inflammatory and nutritional markers to predict postoperative AL in patients after esophagectomy.

Methods: A total of 273 patients were retrospectively evaluated and enrolled into this study. Perioperative, surgeryrelated, tumor-related and laboratory tests data were extracted and analyzed. The discriminatory ability and optimal cut-off value was evaluated according to the receiver operating characteristic (ROC) curve analysis. Univariate and multivariate analyses were performed to access the potential risk factors for AL.

Results: The overall incidence of AL was 12.5\% (34/273). C-reactive protein-to-albumin ratio (CRP/ALB ratio) [AUC 0.943 (95\% confidence interval $(\mathrm{Cl})=0.911-0.976, p<0.001)$ ] and operation time [AUC $0.747(95 \% \mathrm{Cl}=0.679-0.815$, $p<0.001)$ ] had the greatest discrimination on AL prediction. Multivariate analysis demonstrated that CRP/ALB ratio and operation time were two independent risk factors for $A L$, and CRP/ALB ratio $(O R=102.909, p<0.001)$ had an advantage over operation time $(\mathrm{OR}=9.363, p=0.020$; Table 3).

Conclusion: Operation time and postoperative CRP/ALB ratio were two independent predictive indexes for AL. Postoperative CRP/ALB ratio greater than 3.00 indicated a high risk of AL. For patients with abnormal postoperative CRP/ALB ratio, early non-operative treatment or surgical intervention are needed to reduce the serious sequelae of AL.
\end{abstract}

Keywords: C-reactive protein, Albumin, Anastomotic leakage, Esophagectomy, Risk factor

\section{Introduction}

Esophageal cancer (EC) is the eighth most common cancer and the sixth leading cause of cancer-related death worldwide [1]. In addition to radiotherapy, chemotherapy, and molecular targeted therapy, surgery is still considered to be the main methods of treatment [2].

\footnotetext{
* Correspondence: drlixiaokun@163.com; dryishen@nju.edu.cn

${ }^{2}$ Department of Cardiothoracic Surgery, Jinling Hospital, School of Medicine, Southeast University, Nanjing, China

${ }^{1}$ Department of Cardiothoracic Surgery, Jinling Hospital, Medical School of Nanjing University, Nanjing, China

Full list of author information is available at the end of the article
}

Among the many possible postoperative complications, anastomotic leakage (AL) is the most common and serious [3]. Although its incidence is gradually decreasing due to the continuous improvement of surgical methods and the gradual popularization of new technologies such as video-assisted or robot-assisted thoracic surgery, AL still occurs in $8.5-25.6 \%$ of patients after esophagectomy [4-9]. AL can not only lead to mediastinitis, peritonitis and other infections, but also to anastomotic stricture, the need for re-operation and recurrence, resulting in prolonged hospital stay and

C C The Author(s). 2021 Open Access This article is licensed under a Creative Commons Attribution 4.0 International License, which permits use, sharing, adaptation, distribution and reproduction in any medium or format, as long as you give appropriate credit to the original author(s) and the source, provide a link to the Creative Commons licence, and indicate if changes were made. The images or other third party material in this article are included in the article's Creative Commons licence, unless indicated otherwise in a credit line to the material. If material is not included in the article's Creative Commons licence and your intended use is not permitted by statutory regulation or exceeds the permitted use, you will need to obtain permission directly from the copyright holder. To view a copy of this licence, visit http://creativecommons.org/licenses/by/4.0/ The Creative Commons Public Domain Dedication waiver (http://creativecommons.org/publicdomain/zero/1.0/) applies to the data made available in this article, unless otherwise stated in a credit line to the data. 
increased mortality [10-13]. Therefore, accurate prediction of the occurrence and prompt prevention of $\mathrm{AL}$ are essential to accelerate the recovery of patients, improve their quality of life and prolong their life survival.

Systemic inflammatory response and nutritional status are closely related to AL. Malnutrition is one of the most important systemic factors causing $\mathrm{AL}$, and the occurrence and development of $\mathrm{AL}$ will raise strong systemic inflammatory response [14, 15]. Various inflammatory and nutritional markers, such as Creactive protein-to-albumin ratio (CRP/ALB ratio), neutrophil to lymphocyte ratio (NLR), platelet to lymphocyte ratio (PLR), lymphocyte to monocyte ratio (LMR), prognostic nutritional index (PNI), have been confirmed as prognostic indicators of esophageal cancer [16-20]. However, the studies regarding predictive value for postoperative AL in patients with esophageal cancer were still few. Therefore, the purpose of this study was to explore the ability of various inflammatory and nutritional markers to predict postoperative $\mathrm{AL}$ in patients after esophagectomy.

\section{Methods}

\section{Patients}

This retrospective study was approved by Jinling Hospital institutional review board and informed consent requirements were waived. From October 2019 to August 2020, 281 patients with esophageal cancer underwent esophagectomy and reconstruction of the esophageal tract at the Department of Cardiothoracic Surgery, Jinling Hospital, Nanjing, China. Among them, 8 patients were excluded for insufficient data of postoperative biochemical parameters. A total of 273 patients were retrospectively evaluated and enrolled into this study.

\section{Data collection}

The following data were extracted and analyzed. (1) Perioperative data including gender, age, body mass index (BMI), preoperative chemotherapy and/or radiotherapy history, smoking history, thoracic operation history, preoperative comorbidities (diabetes and pulmonary diseases); (2) The surgery-related data including American Society of Anesthesiologists (ASA) score, the type of surgery, the duration of operation and nutritional pathway; (3) The tumor-related data including tumor location, tumor histology, tumor differentiation and pathological stages which were classified according to the 8th edition of the TNM classification system [21]; (4) Laboratory tests data were measured on the third postoperative day (POD 3), including white blood cell, lymphocyte, monocyte, neutrocyte, red blood cell, albumin, hemoglobin, thrombocyte, C-reactive protein and glucose.

\section{Inflammatory and nutritional markers}

The inflammatory and nutritional markers were calculated as follows: CRP/ALB ratio [CRP $(\mathrm{mg} / \mathrm{L})$ to albumin $(\mathrm{g} / \mathrm{L})$ ]; NLR [neutrophil $\left(10^{9} / \mathrm{L}\right)$ to lymphocyte $\left(10^{9} / \mathrm{L}\right)$ ]; PLR [platelet $\left(10^{9} / \mathrm{L}\right)$ to lymphocyte $\left(10^{9} / \mathrm{L}\right)$ ]; LMR [lymphocyte $\left(10^{9} / \mathrm{L}\right)$ to monocyte $\left(10^{9} / \mathrm{L}\right)$ ] and PNI [albumin $(\mathrm{g} / \mathrm{L})+0.005 \times$ lymphocyte count $/ \mu \mathrm{L}]$.

\section{Definition of AL}

As the endpoint of this study, $\mathrm{AL}$ was defined as follows: (1) The leakage of intestinal content from the anastomosis led to clinical features (including intestinal contents found in surgical incision or chest tube drains, wound infection, mediastinitis, peritonitis, pneumothorax and empyema) and/or (2) Leakage was detected by imaging examination, endoscopy, or surgical exploration [22].

\section{Statistical analysis}

Statistical analyses were performed using SPSS (version 22.0, SPSS Inc. Chicago, IL, USA). Categorical variables were compared using $X^{2}$ test or Fisher's exact test, continuous variables were compared using Student's t-test and sequential variables were compared using MannWhitney $U$ test. The discriminatory ability and optimal cut-off value was evaluated according to the receiver operating characteristic (ROC) curve analysis. Univariate logistic regression analysis was used to assess the risk factors for $\mathrm{AL}$, and multivariate analysis was performed only for those factors with $p$ value less than 0.05 in the univariate model. All $p$ values of less than 0.05 were considered statistically significant.

\section{Results}

\section{Patient characteristics}

The characteristics of eligible patients with or without AL are summarized in Table 1. A total of 273 patients were included into this study, and the incidence of AL was $12.5 \%(34 / 273)$. The average age of all the enrolled patients was 64.4 years, with more male patients $(78.4 \%$, $214 / 273)$ than female patients $(21.6 \%, 59 / 273)$. The occurrence of $\mathrm{AL}$ was significantly associated with low ASA score $(\mathrm{U}=3205, \mathrm{z}=-2.452, \quad p=0.014)$, open operation $(p=0.006)$, long operation time $(p<0.001)$, abnormal level of postoperative albumin $(p<0.001)$, hemoglobin $(\mathrm{Hb})(p=0.015)$, C-reactive protein (CRP) $(p<0.001)$, C-reactive protein to albumin ratio (CRP/ ALB ratio $)(p<0.001)$ and prognostic nutritional index (PNI) $(p=0.034)$. There was also a potential correlation of male patients with AL $(p=0.053)$. However, we detected no significant associations between AL and age, BMI, preoperative chemotherapy and/or radiotherapy, diabetes, smoking, thoracic operation history, pulmonary diseases, tumor location, histology, differentiation, 
Table 1 Clinicopathological, operative and biochemical variables associated with AL

\begin{tabular}{|c|c|c|c|c|}
\hline Variable & All $(n=273)$ & Non-AL $(n=239)$ & $\mathrm{AL}(n=34)$ & $p$ value \\
\hline Gender & & & & 0.053 \\
\hline Male & $214(78.4)$ & $183(76.6)$ & $31(91.2)$ & \\
\hline Female & $59(21.6)$ & $56(23.4)$ & $3(8.8)$ & \\
\hline Age (years) & $64.4 \pm 8.8$ & $64.3 \pm 8.9$ & $64.8 \pm 8.4$ & 0.853 \\
\hline $\mathrm{BMI}\left(\mathrm{kg} / \mathrm{m}^{2}\right)$ & $22.94 \pm 3.18$ & $22.99 \pm 3.25$ & $22.56 \pm 2.67$ & 0.491 \\
\hline Preoperative chemotherapy and/or radiotherapy & & & & 0.198 \\
\hline No & $228(83.5)$ & $197(82.4)$ & $31(91.2)$ & \\
\hline Yes & $45(16.5)$ & $42(17.6)$ & $3(8.8)$ & \\
\hline Diabetes & & & & 0.720 \\
\hline No & $253(92.7)$ & $222(92.9)$ & $31(91.2)$ & \\
\hline Yes & $20(7.3)$ & $17(7.1)$ & $3(8.8)$ & \\
\hline Smoking & & & & 0.302 \\
\hline No & $135(50.5)$ & $121(50.6)$ & $14(41.2)$ & \\
\hline Yes & $138(49.5)$ & $118(49.4)$ & $20(58.8)$ & \\
\hline Thoracic operation history & & & & 0.592 \\
\hline No & $271(99.3)$ & $237(99.2)$ & $34(100)$ & \\
\hline Yes & $2(0.7)$ & $2(0.8)$ & $0(0)$ & \\
\hline Pulmonary diseases & & & & 0.271 \\
\hline No & $270(98.9)$ & $237(99.2)$ & $33(97.1)$ & \\
\hline Yes & $3(1.1)$ & $2(0.8)$ & $1(2.9)$ & \\
\hline ASA score & & & & 0.014 \\
\hline 1 & $187(68.5)$ & $157(65.7)$ & $30(88.2)$ & \\
\hline 2 & $72(26.4)$ & $70(29.3)$ & $2(5.9)$ & \\
\hline 3 & $14(5.1)$ & $12(5.0)$ & $2(5.9)$ & \\
\hline Tumor location & & & & 0.336 \\
\hline Upper & $20(7.3)$ & $19(7.9)$ & $1(2.9)$ & \\
\hline Middle & $164(60.1)$ & $140(58.6)$ & $24(70.6)$ & \\
\hline Lower & $89(32.6)$ & $80(33.5)$ & $9(26.5)$ & \\
\hline Histology & & & & 0.370 \\
\hline SCC & $256(93.8)$ & $224(93.7)$ & $32(94.1)$ & \\
\hline$A C$ & $2(0.7)$ & $2(0.8)$ & $0(0)$ & \\
\hline ASC & $2(0.7)$ & $1(0.4)$ & $1(2.9)$ & \\
\hline Other ${ }^{a}$ & $13(4.8)$ & $12(5.0)$ & $1(2.9)$ & \\
\hline Differentiation & & & & 0.883 \\
\hline Well & $71(26.0)$ & $61(25.5)$ & $10(29.4)$ & \\
\hline Moderate & $158(57.9)$ & $139(58.2)$ & $19(55.9)$ & \\
\hline Poor & $44(16.1)$ & $39(16.3)$ & $5(14.7)$ & \\
\hline Pathological Stage & & & & 0.199 \\
\hline I & $104(38.1)$ & 90 (37.6) & $14(41.2)$ & \\
\hline$\|$ & $62(22.7)$ & $59(24.7)$ & $3(8.8)$ & \\
\hline III & $101(37.0)$ & $86(36.0)$ & $15(44.1)$ & \\
\hline IV & $6(2.2)$ & $4(1.7)$ & $2(5.9)$ & \\
\hline Operation type & & & & 0.006 \\
\hline Open operation & $137(50.2)$ & $128(53.6)$ & $9(26.5)$ & \\
\hline
\end{tabular}


Table 1 Clinicopathological, operative and biochemical variables associated with AL (Continued)

\begin{tabular}{|c|c|c|c|c|}
\hline Variable & All $(n=273)$ & Non-AL $(n=239)$ & $\mathrm{AL}(n=34)$ & $p$ value \\
\hline VATS & $97(35.5)$ & $77(32.2)$ & $20(58.8)$ & \\
\hline RATS & $39(14.3)$ & $34(14.2)$ & $5(14.7)$ & \\
\hline Duration of operation (hours) & $3.96 \pm 1.18$ & $3.83 \pm 1.15$ & $4.88 \pm 0.97$ & $<0.001$ \\
\hline Nutritional pathway & & & & 0.217 \\
\hline Jejunostomy tube & $31(11.4)$ & $25(10.5)$ & $6(17.6)$ & \\
\hline Nasojejunal tube & $242(88.6)$ & $214(89.5)$ & $28(82.4)$ & \\
\hline Postoperative WBC $\left(10^{9} / \mathrm{L}\right)$ & $11.14 \pm 3.36$ & $11.19 \pm 3.33$ & $10.80 \pm 3.62$ & 0.671 \\
\hline Postoperative lymphocyte $\left(10^{9} / \mathrm{L}\right)$ & $0.69 \pm 0.35$ & $0.70 \pm 0.36$ & $0.61 \pm 0.29$ & 0.194 \\
\hline Postoperative monocyte $\left(10^{9} / \mathrm{L}\right)$ & $0.61 \pm 0.25$ & $0.60 \pm 0.24$ & $0.61 \pm 0.32$ & 0.871 \\
\hline Postoperative neutrocyte $\left(10^{9} / \mathrm{L}\right)$ & $9.77 \pm 3.19$ & $9.81 \pm 3.18$ & $9.51 \pm 3.30$ & 0.791 \\
\hline Postoperative RBC $\left(10^{12} / \mathrm{L}\right)$ & $3.89 \pm 0.60$ & $3.91 \pm 0.58$ & $3.75 \pm 0.67$ & 0.273 \\
\hline Postoperative albumin (g/L) & $33.75 \pm 3.69$ & $34.11 \pm 3.50$ & $31.2 \pm 0$ & $<0.001$ \\
\hline Postoperative $\mathrm{Hb}(\mathrm{g} / \mathrm{L})$ & $118.5 \pm 19.0$ & $119.3 \pm 19.0$ & $112.5 \pm 17.7$ & 0.015 \\
\hline Postoperative platelet $\left(10^{9} / \mathrm{L}\right)$ & $179.08 \pm 56.87$ & $178.91 \pm 55.37$ & $180.29 \pm 67.43$ & 0.703 \\
\hline Postoperative CRP (mg/L) & $71.19 \pm 63.71$ & $56.45 \pm 47.70$ & $174.82 \pm 66.35$ & $<0.001$ \\
\hline Postoperative glucose (mmol/L) & $8.42 \pm 2.94$ & $8.50 \pm 3.03$ & $7.86 \pm 2.13$ & 0.313 \\
\hline Postoperative CRP/ALB ratio & $2.19 \pm 2.12$ & $1.69 \pm 1.50$ & $5.74 \pm 2.43$ & $<0.001$ \\
\hline Postoperative NLR & $18.74 \pm 13.02$ & $18.41 \pm 12.64$ & $21.04 \pm 15.42$ & 0.482 \\
\hline Postoperative PLR & $320.31 \pm 186.99$ & $312.87 \pm 176.75$ & $372.62 \pm 244.30$ & 0.239 \\
\hline Postoperative LMR & $1.42 \pm 1.31$ & $1.42 \pm 1.32$ & $1.36 \pm 1.23$ & 0.442 \\
\hline Postoperative PNI & $68.29 \pm 18.48$ & $69.21 \pm 18.74$ & $61.81 \pm 15.27$ & 0.034 \\
\hline
\end{tabular}

Data are presented as $\mathrm{n}(\%)$ or mean \pm standard deviation (SD)

$A L$ anastomotic leakage, BMI body mass index, ASA score American Society of Anesthesiologists (ASA) score, SCC squamous cell carcinoma, AC adenocarcinoma, $A S C$ adenosquamous carcinoma, VATS video-assisted thoracic surgery, RATS robot-assisted thoracic surgery, WBC white blood cell, $R B C$ red blood cell, $H b$ hemoglobin, CRP C-reactive protein, CRP/ALB ratio C-reactive protein to albumin ratio, NLR neutrophil to lymphocyte ratio, $P L R$ platelet to lymphocyte ratio, $L M R$ lymphocyte to monocyte ratio, $P N I$ prognostic nutritional index

${ }^{a}$ Carcinoid tumors $(n=9)$, sarcomas $(n=2)$ and lymphomas $(n=2)$

pathological stage, nutritional pathway, white blood cell (WBC), lymphocyte, monocyte, neutrocyte, red blood cell (RBC), thrombocyte, glucose, neutrophil to lymphocyte ratio (NLR), platelet to lymphocyte ratio (PLR) and lymphocyte to monocyte ratio (LMR) $(p>0.1)$.

\section{Cut-off value of inflammatory and nutritional markers}

The optimal cut-off value was determined according to the receiver operating characteristic (ROC) curve (Table 2 and Fig. 1). Among them, CRP/ALB ratio [AUC
0.943 (95\% confidence interval $(\mathrm{CI})=0.911-0.976$, $p<0.001)$ ] and operation time [AUC $0.747(95 \% \mathrm{CI}=$ $0.679-0.815, p<0.001)]$ had the greatest discrimination on $\mathrm{AL}$ prediction, PNI [AUC $0.612(95 \% \mathrm{CI}=0.506-$ $0.719, p=0.034)$ ] were also effective predictors for AL.

\section{Risk factors for $\mathrm{AL}$}

C-reactive protein and albumin were excluded from the univariate and multivariate models due to their statistical correlation with CRP/ALB ratio. Lymphocyte, monocyte,

Table 2 Receiver operating characteristic analysis for each factor

\begin{tabular}{|c|c|c|c|c|c|}
\hline Variable & Cut off & Sensitivity & Specificity & $\mathrm{AUC}(95 \% \mathrm{Cl})$ & $p$ value \\
\hline Duration of operation (hours) & 3.65 & $94.12 \%$ & $52.30 \%$ & $0.747(0.679-0.815)$ & $<0.001$ \\
\hline Postoperative CRP/ALB ratio & 3.00 & $88.24 \%$ & $90.38 \%$ & $0.943(0.911-0.976)$ & $<0.001$ \\
\hline Postoperative NLR & 18.38 & $52.95 \%$ & $62.34 \%$ & $0.537(0.428-0.646)$ & 0.482 \\
\hline Postoperative PLR & 255.00 & $76.47 \%$ & $45.61 \%$ & $0.562(0.460-0.664)$ & 0.239 \\
\hline Postoperative LMR & 1.04 & $61.76 \%$ & $54.81 \%$ & $0.541(0.429-0.652)$ & 0.442 \\
\hline Postoperative PNI & 58.90 & $52.94 \%$ & $69.87 \%$ & $0.612(0.506-0.719)$ & 0.034 \\
\hline
\end{tabular}

AUC area under the curve, $C l$ confidence interval, $C R P / A L B$ ratio C-reactive protein to albumin ratio, NLR neutrophil to lymphocyte ratio, $P L R$ platelet to lymphocyte ratio, $L M R$ lymphocyte to monocyte ratio, $P N I$ prognostic nutritional index 

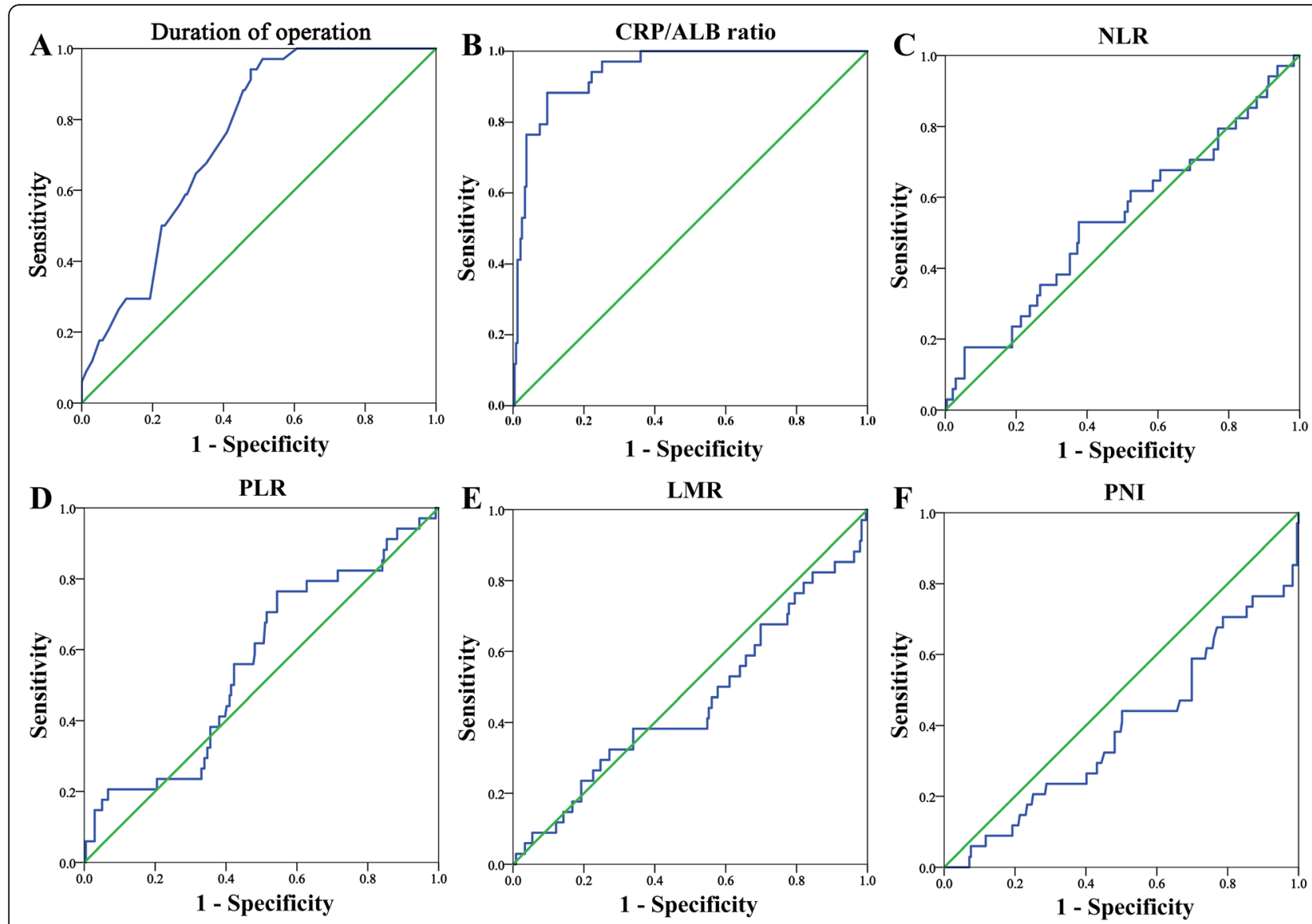

Fig. 1 The receiver operating characteristic (ROC) curves for the Duration of operation (a), CRP/ALB ratio (b), NLR (c), PLR (d), LMR (e), and PNI (f). CRP/ALB ratio, C-reactive protein to albumin ratio; NLR, neutrophil to lymphocyte ratio; PLR, platelet to lymphocyte ratio; LMR, lymphocyte to monocyte ratio; PNI, prognostic nutritional index

neutrocyte and platelet were excluded for the same reason. Univariate analysis showed that ASA score, operation type, operation time, postoperative $\mathrm{Hb}, \mathrm{CRP} / \mathrm{ALB}$ ratio, PLR and PNI were risk factors for AL $(p<0.05)$, whereas multivariate analysis demonstrated that CRP/ ALB ratio and operation time were two independent risk factors for $\mathrm{AL}$, and CRP/ALB ratio $(\mathrm{OR}=102.909$, $p<0.001)$ had an advantage over operation time (OR = 9.363, $p=0.020$; Table 3).

\section{Discussion}

As the most common and serious postoperative complications after esophagectomy, AL has always been the focus of research. People have been constantly exploring the most closely related risk factors in order to accurately predict the occurrence of AL. In the present study, seven risk factors for AL including ASA score, operation type, operation time, postoperative $\mathrm{Hb}$, CRP/ALB ratio, PLR and PNI were shown in univariate analysis. However, multivariate analysis identifies that only postoperative CRP/ALB ratio and operation time were two independent risk factors for AL. The overall incidence of $\mathrm{AL}$ in this study was $12.5 \%$, which was similar to that reported in other clinical reports.

Lower BMI have been reported to be associated with high risk of AL by Scipione et al. [23] which may be attributed to nutritional status. A study of non-surgical factors for AL found low hemoglobin predisposes to AL as a result of abnormal hemodynamic and oxygenation [24]. In several previous studies, no relationship between ASA score and AL was found [24, 25]. In our univariate analysis, the incidence of AL was lower in patients with score 2 than in patients with score 1, though the overall condition of a score 2 was poorer. Further research is needed to confirm this result and analyze its biological mechanism. As revealed by the Society of Thoracic Surgeons [26], operation time greater than $5 \mathrm{~h}$ was a significant risk factor for AL. Our results showed that the optimal cut-off value was $3.7 \mathrm{~h}$. Long operation time reflects difficulties during operation, leading to technical failure of anastomosis. A meta-analysis by Guo et al. [27] found no significant difference in AL between 
Table 3 Univariate and multivariate analysis of factors affecting AL after esophagectomy

\begin{tabular}{|c|c|c|c|c|c|}
\hline \multirow[t]{2}{*}{ Variable } & \multirow{2}{*}{$\begin{array}{l}\text { Number } \\
\text { (\%) }\end{array}$} & \multicolumn{2}{|l|}{ Univariate analysis } & \multicolumn{2}{|l|}{ Multivariate analysis } \\
\hline & & $\mathrm{OR}(95 \% \mathrm{Cl})$ & $p$ value & $\mathrm{OR}(95 \% \mathrm{Cl})$ & $p$ value \\
\hline Age (years) & & & & $0.995(0.925-1.069)$ & 0.882 \\
\hline $\mathrm{BMI}\left(\mathrm{kg} / \mathrm{m}^{2}\right)$ & & & & $0.918(0.735-1.147)$ & 0.453 \\
\hline ASA score & & & 0.014 & & 0.169 \\
\hline 1 & $187(68.5)$ & 1 & & 1 & \\
\hline 2 & $72(26.4)$ & $0.150(0.035-0.643)$ & & 0.143(0.017-1.182) & \\
\hline 3 & $14(5.1)$ & $0.872(0.186-4.097)$ & & $0.421(0.033-5.439)$ & \\
\hline Operation type & & & 0.006 & & 0.246 \\
\hline Open operation & 137(50.2) & 1 & & 1 & \\
\hline VATS & $97(35.5)$ & $3.694(1.601-8.522)$ & & $2.656(0.540-13.073)$ & \\
\hline RATS & $39(14.3)$ & 2.092(0.658-6.650) & & $0.693(0.103-4.686)$ & \\
\hline Duration of operation (hours) & & & 0.000 & & 0.020 \\
\hline$<3.7$ & $127(46.5)$ & 1 & & 1 & \\
\hline$\geq 3.7$ & $146(53.5)$ & $17.544(4.111-74.861)$ & & $9.363(1.416-61.909)$ & \\
\hline Postoperative WBC $\left(10^{9} / \mathrm{L}\right)$ & & & 0.870 & & 0.145 \\
\hline$<9.5$ & $85(31.1)$ & 1 & & 1 & \\
\hline$\geq 9.5$ & 188(68.9) & $0.938(0.435-2.023)$ & & $0.318(0.068-20.532)$ & \\
\hline Postoperative RBC $\left(10^{12} / \mathrm{L}\right)$ & & & 0.114 & & 0.155 \\
\hline$<4.0$ & 134(49.1) & 1 & & 1 & \\
\hline$\geq 4.0$ & 139(50.9) & $0.555(0.266-1.160)$ & & $3.562(0.618-20.532)$ & \\
\hline Postoperative Hb (g/L) & & & 0.001 & & 0.121 \\
\hline$<120$ & 130(47.6) & 1 & & 1 & \\
\hline$\geq 120$ & 143(52.4) & $0.282(0.126-0.630)$ & & $0.246(0.042-1.446)$ & \\
\hline Postoperative glucose (mmol/L) & & & & 0.945(0.772-1.156) & 0.582 \\
\hline Postoperative CRP/ALB ratio & & & 0.000 & & $<0.001$ \\
\hline$<3.00$ & $220(80.6)$ & 1 & & 1 & \\
\hline$\geq 3.00$ & $53(19.4)$ & $70.435(22.790-217.687)$ & & $102.909(22.522-470.224)$ & \\
\hline Postoperative NLR & & & 0.088 & & 0.788 \\
\hline$<18.38$ & $165(60.4)$ & 1 & & 1 & \\
\hline$\geq 18.38$ & 108(39.6) & 1.863(0.904-3.836) & & 1.318(0.176-9.874) & \\
\hline Postoperative PLR & & & 0.015 & & 0.254 \\
\hline$<255.00$ & $117(42.9)$ & 1 & & 1 & \\
\hline$\geq 255.00$ & 156(57.1) & $2.725(1.186-6.264)$ & & $2.818(0.476-16.689)$ & \\
\hline Postoperative LMR & & & 0.070 & & 0.851 \\
\hline$<1.04$ & 129(47.3) & 1 & & 1 & \\
\hline$\geq 1.04$ & 144(52.7) & $0.510(0.244-1.067)$ & & $0.843(0.142-5.024)$ & \\
\hline Postoperative PNI & & & 0.008 & & 0.856 \\
\hline$<58.90$ & 90(33.0) & 1 & & 1 & \\
\hline$\geq 58.90$ & 183(67.0) & $0.383(0.185-0.794)$ & & $1.219(0.125-11.888)$ & \\
\hline
\end{tabular}

Data are presented as $\mathrm{n}(\%)$

$O R$ odds ratio, $C l$ confidence interval, $B M I$ body mass index, $A S A$ score American Society of Anesthesiologists (ASA) Score, VATS video-assisted thoracic surgery, RATS robot-assisted thoracic surgery, WBC white blood cell, $R B C$ red blood cell, Hb hemoglobin, CRP/ALB ratio C-reactive protein to albumin ratio, NLR neutrophil to lymphocyte ratio, $P L R$ platelet to lymphocyte ratio, $L M R$ lymphocyte to monocyte ratio, $P N I$ prognostic nutritional index 
video-assisted thoracic surgery (VATS) and open surgery. In our study, univariate analysis showed that VATS had an increased risk of AL, but no significant difference were found between robot-assisted thoracic surgery (RATS) and open surgery. Consistent with our results, Lipska et al. [25] also found that male patients were more likely to develop AL, which may be related to hormonal differences affecting intestinal microcirculation. No previous study reported age and TNM stage to be associated with increased risk of AL, nor did our study. Girard et al. [28] reported diabetes and smoking increase the risk of AL, however, this association were not found in this present study.

The biological mechanism of AL has not been adequately researched. It is widely accepted that any reason cause ischemia of the alimentary canal will lead to poor healing of anastomosis. Immune and nutritional status have been demonstrated to be associated with postoperative complications and survival in previous studies [3]. Several studies have confirmed that low serum protein can affect the blood supply and oxygenation of the anastomosis, making it more prone to AL [29, 30]. Serum albumin is an indicator of nutritional status and hypoalbuminemia usually leads to a poor prognosis. Also, it can also be used as an acute phase protein to mediate inflammatory response [31]. According to Warschkow et al. [32], the serum concentration of CRP reflected the stimulation intensity of acute inflammatory reaction and increased before the development of postoperative infectious complications, and the POD 3 or 4 CRP level was widely recommended for the prediction and diagnosis of postoperative AL [33, 34].

Compared with CRP or albumin alone, CRP/ALB ratio is a preferable indicator of immune response and nutritional status [35]. And CRP/ALB ratio has been used as a prognostic factor in variety of solid cancers including esophageal cancer, lung cancer, gastric cancer, colorectal cancer and so on [36-39]. Recent reports by $\mathrm{Yu}$ et al. have found preoperative CRP/ALB ratio was an independent risk factor for AL in elderly colorectal cancer patients with a cut-off value of 2.44 [40]. Our study further indicated that postoperative CRP/ALB ratio was also an independent risk factor for AL after esophagectomy. According to our analysis, the optimal cut-off value of postoperative CRP/ALB ratio was 3.00.

Our study has also found that PLR and PNI were risk factors for AL. They are also effective predictors of the prognosis and complications of many solid cancers as the same with CRP/ALB ratio $[18,41]$, and are calculated from platelet, lymphocyte and albumin. The detection of lymphocyte number in peripheral blood can reflecting the immune level to a certain extent, and the decrease of lymphocyte number indicates low function of immune system [42]. Platelets are also closely related to the development of tumors and distant metastasis. Thrombocytosis is common among patients with malignant tumors [43]. However, the pathophysiological relationship between them and AL is still not clear, which needs further study.

\section{Limitation}

This study has several limitations. First, this is a retrospective study from our single center, and the number of patients is not sufficient enough. Second, due to lack of laboratory data, we did not compare the predictive ability of preoperative and postoperative CRP/ALB ratio for AL. Third, the biological mechanism of CRP/ALB ratio in predicting AL was still unclear. More prospectively multicenter clinical studies were needed to explore the correlation and mechanism of CRP/ALB ratio with AL in patients after esophagectomy.

\section{Conclusion}

Operation time and postoperative CRP/ALB ratio were two independent predictive indexes for AL. Postoperative CRP/ALB ratio greater than 3.00 indicated a high risk of AL. For patients with abnormal postoperative $\mathrm{CRP} / \mathrm{ALB}$ ratio, early non-operative treatment or surgical intervention are needed to reduce the serious sequelae of AL.

\section{Abbreviations}

AL: Anastomotic leakage; EC: Esophageal cancer; CRP/ALB ratio: C-reactive protein-to-albumin ratio; NLR: Neutrophil to lymphocyte ratio; PLR: Platelet to lymphocyte ratio; LMR: Lymphocyte to monocyte ratio; PNI: Prognostic nutritional index; BMI: Body mass index; ASA score: American Society of Anesthesiologists score; POD: Postoperative day; ROC: Receiver operating characteristic; VATS: Video-assisted thoracic surgery; RATS: Robot-assisted thoracic surgery

\section{Acknowledgements}

The authors would like to acknowledge the support of all colleagues in department of Cardiothoracic Surgery in Jingling Hospital.

\section{Authors' contributions}

$\mathrm{ZC}$ and $\mathrm{LXK}$ conceived of the idea and were major contributors in writing the manuscript; ZC and HLW collected the data; GWF, and ZC performed the statistical analysis. All authors contributed to the interpretation of the results and critically reviewed the first draft. All authors read and approved the final manuscript.

\section{Funding}

This work was supported by the National Natural Science Foundation of China [81702444] and the Natural Science Foundation of Jiangsu Province [BK20181239].

\section{Availability of data and materials}

This study is based on data retrieved from a hospital medical record system. All personal data have been protected and secured according to current national and international laws.

\section{Declarations}

Ethics approval and consent for participate

The study was conducted in accordance with the Declaration of Helsinki (as revised in 2013) and the Harmonized Tripartite Guideline for Good Clinical Practice from the International Conference on Harmonization. This study was 
approved by the Institutional Review Board of the Jinling Hospital and individual consent for this retrospective analysis was waived.

\section{Consent for publication}

Written informed consent for publication was obtained from all participants.

\section{Competing interests}

None declared.

\section{Author details}

'Department of Cardiothoracic Surgery, Jinling Hospital, Medical School of Nanjing University, Nanjing, China. '2Department of Cardiothoracic Surgery, Jinling Hospital, School of Medicine, Southeast University, Nanjing, China. ${ }^{3}$ Department of Cardiothoracic Surgery, Jinling Hospital, School of Clinical Medicine, Nanjing Medical University, Nanjing, China. ${ }^{4}$ Department of Thoracic Surgery, Xuzhou Central Hospital, Xuzhou School of Clinical Medicine of Nanjing Medical University, Nanjing, China. ${ }^{5}$ Department of Cardiothoracic Surgery, Jinling Hospital, School of Clinical Medicine, Southern Medical University, Guangzhou, China.

\section{Received: 5 April 2021 Accepted: 7 May 2021}

\section{Published online: 17 May 2021}

\section{References}

1. Bray F, Ferlay J, Soerjomataram I, Siegel RL, Torre LA, Jemal A. Global cancer statistics 2018: GLOBOCAN estimates of incidence and mortality worldwide for 36 cancers in 185 countries. CA Cancer J Clin. 2018;68(6):394-424. https://doi.org/10.3322/caac.21492.

2. Kato $H$, Nakajima M. Treatments for esophageal cancer: a review. Gen Thorac Cardiovasc Surg. 2013;61(6):330-5. https://doi.org/10.1007/s11748013-0246-0

3. Jones CE, Watson TJ. Anastomotic leakage following esophagectomy Thorac Surg Clin. 2015;25(4):449-59. https://doi.org/10.1016/j.thorsurg.2015. 07.004

4. Liu YJ, Fan J, He HH, Zhu SS, Chen QL, Cao RH. Anastomotic leakage after intrathoracic versus cervical oesophagogastric anastomosis for oesophageal carcinoma in Chinese population: a retrospective cohort study. BMJ Open. 2018:8(9):e021025. https://doi.org/10.1136/bmjopen-2017-021025.

5. Borggreve AS, Goense L, van Rossum PSN, van Hillegersberg R, de Jong PA, Ruurda JP. Generalized cardiovascular disease on a preoperative CT scan is predictive for anastomotic leakage after esophagectomy. Eur J Surg Oncol. 2018;44(5):587-93. https://doi.org/10.1016/j.ejso.2018.01.225

6. Belmouhand M, Svendsen LB, Kofoed SC, Normann G, Baeksgaard L, Achiam $M P$. Recurrence following curative intended surgery for an adenocarcinoma in the gastroesophageal junction: a retrospective study. Dis Esophagus. 2018;31(4):10.1093/dote/dox136. https://doi.org/10.1093/dote/dox136.

7. Andreou A, Biebl M, Dadras M, Struecker B, Sauer IM, Thuss-Patience PC, et al. Anastomotic leak predicts diminished long-term survival after resection for gastric and esophageal cancer. Surgery. 2016;160(1):191-203. https://doi.org/10.1016/j.surg.2016.02.020.

8. Markar S, Gronnier C, Duhamel A, Mabrut JY, Bail JP, Carrere N, et al. The impact of severe anastomotic leak on long-term survival and cancer recurrence after surgical resection for esophageal malignancy. Ann Surg. 2015;262(6):972-80. https://doi.org/10.1097/SLA.0000000000001011.

9. Kofoed SC, Calatayud D, Jensen LS, Helgstrand F, Achiam MP, De Heer P, et al. Intrathoracic anastomotic leakage after gastroesophageal cancer resection is associated with increased risk of recurrence. J Thorac Cardiovasc Surg. 2015:150(1):42-8, https://doi.org/10.1016/j.jtcvs.2015.04.030.

10. Connors RC, Reuben BC, Neumayer LA, Bull DA. Comparing outcomes after transthoracic and transhiatal esophagectomy: a 5-year prospective cohort of 17,395 patients. J Am Coll Surg. 2007;205(6):735-40. https://doi.org/10.1016/ j.jamcollsurg.2007.07.001.

11. Tabatabai A, Hashemi M, Mohajeri G, Ahmadinejad M, Khan IA, Haghdani S. Incidence and risk factors predisposing anastomotic leak after transhiata esophagectomy. Ann Thorac Med. 2009:4(4):197-200. https://doi.org/10.41 03/1817-1737.56012

12. Rutegard M, Lagergren $P$, Rouvelas I, Lagergren J. Intrathoracic anastomotic leakage and mortality after esophageal cancer resection: a populationbased study. Ann Surg Oncol. 2012;19(1):99-103. https://doi.org/10.1245/s1 0434-011-1926-6.
13. Whooley BP, Law S, Alexandrou A, Murthy SC, Wong J. Critical appraisal of the significance of intrathoracic anastomotic leakage after esophagectomy for cancer. Am J Surg. 2001;181(3):198-203. https://doi.org/10.1016/S00029610(01)00559-1.

14. Tsujimoto H, Ono S, Takahata R, Hiraki S, Yaguchi Y, Kumano I, et al. Systemic inflammatory response syndrome as a predictor of anastomotic leakage after esophagectomy. Surg Today. 2012;42(2):141-6. https://doi. org/10.1007/s00595-011-0049-9.

15. Patil PK, Patel SG, Mistry RC, Deshpande RK, Desai PB. Cancer of the esophagus: esophagogastric anastomotic leak--a retrospective study of predisposing factors. J Surg Oncol. 1992:49(3):163-7. https://doi.org/10.1002/ jso.2930490307.

16. Zhang $Y$, Xiao G, Wang R. Clinical significance of systemic immuneinflammation index (SII) and C-reactive protein-to-albumin ratio (CAR) in patients with esophageal cancer: a meta-analysis. Cancer Manag Res. 2019; 11:4185-200. https://doi.org/10.2147/CMAR.S190006.

17. Han F, Liu Y, Cheng S, Sun Z, Sheng C, Sun X, et al. Diagnosis and survival values of neutrophil-lymphocyte ratio (NLR) and red blood cell distribution width (RDW) in esophageal cancer. Clin Chim Acta. 2019;488:150-8. https:// doi.org/10.1016/j.cca.2018.10.042.

18. Deng J, Zhang $P$, Sun $Y$, Peng $P$, Huang Y. Prognostic and clinicopathological significance of platelet to lymphocyte ratio in esophageal cancer: a meta-analysis. J Thorac Dis. 2018;10(3):1522-31. https://doi.org/10.21037/jtd.2018.02.58.

19. Li KJ, Xia XF, Su M, Zhang H, Chen WH, Zou CL. Predictive value of lymphocyte-to-monocyte ratio (LMR) and neutrophil-to-lymphocyte ratio (NLR) in patients with oesophageal cancer undergoing concurrent chemoradiotherapy. BMC Cancer. 2019;19(1):1004. https://doi.org/10.1186/ s12885-019-6157-4.

20. Okadome K, Baba Y, Yagi T, Kiyozumi Y, Ishimoto T, Iwatsuki M, et al. Prognostic nutritional index, tumor-infiltrating lymphocytes, and prognosis in patients with esophageal cancer. Ann Surg. 2020;271(4):693-700. https:// doi.org/10.1097/SLA.0000000000002985.

21. Rice TW, Ishwaran H, Ferguson MK, Blackstone EH, Goldstraw P. Cancer of the esophagus and esophagogastric junction: an eighth edition staging primer. J Thorac Oncol. 2017;12(1):36-42. https://doi.org/10.1016/j.jtho.201 6.10.016.

22. Peel AL, Taylor EW. Proposed definitions for the audit of postoperative infection: a discussion paper. Surgical Infection Study Group. Ann R Coll Surg Engl. 1991;73(6):385-8.

23. Scipione $\mathrm{CN}$, Chang AC, Pickens A, Lau CL, Orringer MB. Transhiatal esophagectomy in the profoundly obese: implications and experience. Ann Thorac Surg. 2007:84(2):376-82; discussion 383. https://doi.org/10.1016/j.a thoracsur.2006.11.070.

24. Choudhuri AH, Uppal R, Kumar M. Influence of non-surgical risk factors on anastomotic leakage after major gastrointestinal surgery: audit from a tertiary care teaching institute. Int J Crit IIIn Inj Sci. 2013;3(4):246-9. https:// doi.org/10.4103/2229-5151.124117.

25. Lipska MA, Bissett IP, Parry BR, Merrie AE. Anastomotic leakage after lower gastrointestinal anastomosis: men are at a higher risk. ANZ J Surg. 2006; 76(7):579-85. https://doi.org/10.1111/j.1445-2197.2006.03780.x.

26. Kassis ES, Kosinski AS, Ross P Jr, Koppes KE, Donahue JM, Daniel VC. Predictors of anastomotic leak after esophagectomy: an analysis of the society of thoracic surgeons general thoracic database. Ann Thorac Surg. 2013;96(6):1919-26. https://doi.org/10.1016/j.athoracsur.2013.07.119.

27. Guo W, Ma X, Yang S, Zhu X, Qin W, Xiang J, et al. Combined thoracoscopic-laparoscopic esophagectomy versus open esophagectomy: a meta-analysis of outcomes. Surg Endosc. 2016;30(9):3873-81. https://doi. org/10.1007/s00464-015-4692-X

28. Girard E, Messager M, Sauvanet A, Benoist S, Piessen G, Mabrut JY, et al. Anastomotic leakage after gastrointestinal surgery: diagnosis and management. J Visc Surg. 2014;151(6):441-50. https://doi.org/10.1016/j. jviscsurg.2014.10.004

29. Alves A, Panis Y, Trancart D, Regimbeau JM, Pocard M, Valleur P. Factors associated with clinically significant anastomotic leakage after large bowel resection: multivariate analysis of 707 patients. World J Surg. 2002;26(4):499502. https://doi.org/10.1007/s00268-001-0256-4.

30. lancu C, Mocan LC, Todea-lancu D, Mocan T, Acalovschi I, lonescu D, et al. Host-related predictive factors for anastomotic leakage following large bowel resections for colorectal cancer. J Gastrointestin Liver Dis. 2008;17(3): 299-303. 
31. Wu N, Chen G, Hu H, Pang L, Chen Z. Low pretherapeutic serum albumin as a risk factor for poor outcome in esophageal squamous cell carcinomas. Nutr Cancer. 2015;67(3):481-5. https://doi.org/10.1080/01635581.2015.1004 726.

32. Warschkow R, Beutner U, Steffen T, Muller SA, Schmied BM, Guller U, et al. Safe and early discharge after colorectal surgery due to C-reactive protein: a diagnostic meta-analysis of 1832 patients. Ann Surg. 2012;256(2):245-50. https://doi.org/10.1097/SLA.0b013e31825b60fo.

33. Benedetti M, Ciano P, Pergolini I, Ciotti S, Guercioni G, Ruffo G, Borghi F, Patriti A, Del Rio P, Scatizzi M et al: Early diagnosis of anastomotic leakage after colorectal surgery by the Dutch leakage score, serum procalcitonin and serum C-reactive protein: study protocol of a prospective multicentre observational study by the Italian ColoRectal Anastomotic Leakage (iC. G Chir 2019, 40(1):20-25.

34. Aiolfi A, Asti E, Rausa E, Bonavina G, Bonitta G, Bonavina L. Use of C-reactive protein for the early prediction of anastomotic leak after esophagectomy: systematic review and Bayesian meta-analysis. PLoS One. 2018;13(12): e0209272. https://doi.org/10.1371/journal.pone.0209272.

35. Ge X, Cao Y, Wang H, Ding C, Tian H, Zhang $X$, et al. Diagnostic accuracy of the postoperative ratio of $\mathrm{C}$-reactive protein to albumin for complications after colorectal surgery. World J Surg Oncol. 2017;15(1):15. https://doi.org/1 0.1186/s12957-016-1092-1.

36. Liu Z, Shi H, Chen L. Prognostic role of pre-treatment C-reactive protein/ albumin ratio in esophageal cancer: a meta-analysis. BMC Cancer. 2019; 19(1):1161. https://doi.org/10.1186/s1 2885-019-6373-y.

37. Fan Y, Xiang S, Dai Z, Zou C, Wang X, Gao Z. Prognostic significance of Creactive protein to albumin ratio in colorectal cancer patients: a metaanalysis. Int J Color Dis. 2019;34(6):1105-11. https://doi.org/10.1007/s00384019-03299-x.

38. Saito H, Kono Y, Murakami Y, Shishido Y, Kuroda H, Matsunaga T, et al. Prognostic significance of the preoperative ratio of $\mathrm{C}$-reactive protein to albumin and neutrophil-lymphocyte ratio in gastric cancer patients. World J Surg. 2018;42(6):1819-25. https://doi.org/10.1007/s00268-017-4400-1.

39. Deng TB, Zhang J, Zhou YZ, Li WM. The prognostic value of C-reactive protein to albumin ratio in patients with lung cancer. Medicine (Baltimore). 2018;97(50):e13505. https://doi.org/10.1097/MD.0000000000013505.

40. Yu Y, Wu Z, Shen Z, Cao Y. Preoperative C-reactive protein-to-albumin ratio predicts anastomotic leak in elderly patients after curative colorectal surgery. Cancer Biomark. 2020;27(3):295-302. https://doi.org/10.3233/CBM-1 90470.

41. Xue Y, Zhou X, Xue L, Zhou R, Luo J. The role of pretreatment prognostic nutritional index in esophageal cancer: a meta-analysis. J Cell Physiol. 2019; 234(11):19655-62. https://doi.org/10.1002/jcp.28565.

42. Junttila MR, de Sauvage FJ. Influence of tumour micro-environment heterogeneity on therapeutic response. Nature. 2013;501 (7467):346-54. https://doi.org/10.1038/nature12626.

43. Zhao L, Li T, Yang Y, Zhang Y, Li W, Han L, et al. Clinical value of neutrophilto-lymphocyte ratio as a predictor of prognosis of RetroNectin((R))-activated cytokine-induced killer cell therapy in advanced non-small-cell lung cancer. Immunotherapy. 2019;1 14):273-82. https://doi.org/10.2217/imt-2018-0147.

\section{Publisher's Note}

Springer Nature remains neutral with regard to jurisdictional claims in published maps and institutional affiliations.

Ready to submit your research? Choose BMC and benefit from:
- fast, convenient online submission
- thorough peer review by experienced researchers in your field
- rapid publication on acceptance
- support for research data, including large and complex data types
- gold Open Access which fosters wider collaboration and increased citations
- maximum visibility for your research: over 100M website views per year
At BMC, research is always in progress.
Learn more biomedcentral.com/submissions

